\title{
BIOLOGICAL AND CHEMICAL EVALUATION OF SOME DRINKING WATER SITES ON THE RIVER NILE, EGYPT
}

(Received: 5. 2.2 008)

\author{
By \\ O. S. Barakat, R. H. Ahmed and A. M. Higazy \\ Department of Agricultural Microbiology, Faculty of Agriculture, Cairo University, Giza, Egypt.
}

\begin{abstract}
A total of 225 representative water samples, from 3 different sites, was collected from Helwan, Giza and Rod El-Farag drinking water treatment plants in the greater Cairo city. In all water samples, fluorine, mercury, lead and cadmium were not detected. While chlorine, nitrate, chromium, nickel, zinc and cupper were found. The raw water of river Nile recorded high counts of all the examined microorganisms. After water treatments, almost all the pathogenic bacteria could not be detected except Bacillus cereus and cyanobacteria. Results indicated that pathogenic bacterial isolates are belonging to the genera Staphylococcus, Salmonella and Aeromonas. Also, B. cereus was isolated from all water samples. The examined bacteria were inhibited by the culture filtrates of the different cyanobacterial isolates. Mycobacterium phlei, B. subtilis and Listeria monocytogenus were the most inhibited by the cyanobacterial filtrates, particularly, when the filtrates were concentrated by lypholization. It is, therefore, concluded that fresh water cyanobacteria is a possible source of water contamination that may harmfully affect the drinking water quality. Therefore, it could be suggested that such approach must be considered in water treatment plants.
\end{abstract}

Key words: bacterial pathogens, chemical pollution, Cyanobacteria, drinking water, River Nile.

\section{INTRODUCTION}

Drinking water is an important resource around the globe. Little research has been focused on identifying the bacteria in water distribution systems or how treatment techniques could alter the composition (Wagner and Loy, 2002). Although the majority of bacterial organisms are probably killed by the chlorination process, during peak microbial water concentration periods and during turbidity events, disinfection effectiveness could be potentially compromised. The majority of these culturable bacteria described in drinking water networks are included in the phylum Proteobacteria and to a lesser extent in the phyla Actinobacteria, Firmicutes and Bacteriodetes (Norton and LeChevallier, 2000). Some of the commonly detected genera include Pseudomonas, Caulobacter, Aeromonas, Acinetobacter and Bacillus. Also, bacterial species that cause gastrointestinal illness in people may include: Campylobacter sp., Clostridium perfringes, Corynebacterium sp., Escherichia coli, Salmonella sp., and Yersinia enterocolitica (Adam et al., 2005 ; Lehtola et al., 2007).

Cyanobacteria form dense growth known as blooms in eutrophicated waters. The presence of these blooms in freshwater bodies can pose a significant threat to the health of humans and animals, as certain species of cyanobacteria can produce toxins. The most important cyanobacterial toxins are the microcystins, which are produced by Microcystis, Planktothrix and Anabaena (Carmichael, 1994).

Production of drinking water complying with international quality standards does not necessarily ensure good drinking water for the consumer (Stefan et al., 2006). Composition of the autochthonous microbial community may promote the survival and growth of hygienically relevant and potentially pathogenic bacteria (LeChevallier, 1990). Several studies helped to characterize some bacteria residing in bulk water (Emtiazi et al., 2004) or in biofilms at various points in the drinking water supply system (Lee and Kim, 2003). The majority of bacterial cells in natural communities are either nonculturable by current cultivation methods or present in a viable butnonculturable state (Oliver, 2000). Thus, the real composition and dynamics of bacterial communities in drinking water distribution systems are far from being assessed and understood in detail. 
The present study was planned to evaluate the microbiological and chemical traits of some drinking water supplies in both Cairo and Giza cities. Samples were collected from the raw water of river Nile before three major water treatment plants and from the treated water out of these plants as well as from different sites among the drinking water supplies network.

\section{MATERIALS AND METHODS}

\subsection{Samples collection and preparation}

Samples were collected from three major drinking water treatment plants, two in Cairo and one in Giza cities. The total was 225 representative samples each of the raw water source (H1, G1 and R1). The treated water outlet from each plants(H2, G2 and R2) and the distribution network water (H3, G3 and R3), were investigated (Table 1). The distribution of network water was sampled from tap water in three different areas in Helwan (H), Giza $(\mathrm{G})$ and Rod El-Farag (R). Sodium thiosulfate was added to neutralize residual chlorine in drinking water samples. Samples were collected three times in August, November 2007 and January 2008. Water samples were stored in ice box during transportation to the laboratory, then immediately analvzed.

Table (1): Description of raw water sources and treatment processes in the 3 water distribution systems.

\begin{tabular}{|c|c|c|c|c|}
\hline Treatment plant & Samples type & $\begin{array}{c}\text { Samples } \\
\text { No. }\end{array}$ & $\begin{array}{c}\text { The total volume } \\
\text { of water produced } \\
\mathbf{m}^{3} / \mathbf{d a y}\end{array}$ & Distribution area \\
\hline \multirow{3}{*}{ Helwan } & Raw water (H1) & 15 & \multirow{3}{*}{370.000} & \multirow{3}{*}{$\begin{array}{l}\text { Helwan, Hadayk Helwan, } \\
\text { Kafr El Elo, Elmshroaa } \\
\text { El Amriky and } 15 \text { May }\end{array}$} \\
\hline & Treated water (H2) & 15 & & \\
\hline & Tap water* & 45 & & \\
\hline \multirow{3}{*}{ Giza } & Raw water $\quad$ (G1) & 15 & \multirow{3}{*}{150.000} & \multirow{3}{*}{$\begin{array}{c}\text { Giza, Bolak Eldakror, El } \\
\text { Haram, El-Malik Faisal }\end{array}$} \\
\hline & Treated water (G2) & 15 & & \\
\hline & Tap water* & 45 & & \\
\hline \multirow{3}{*}{ Rod El-Farag } & Raw water & 15 & \multirow{3}{*}{900.000} & \multirow{3}{*}{$\begin{array}{c}\text { Rod El-Farag, Ramsis, El } \\
\text { Sabteah }\end{array}$} \\
\hline & Treated water (R2) & 15 & & \\
\hline & Tap water * & 45 & & \\
\hline
\end{tabular}

*Tap water at different sites within each distribution system

\subsection{Physico-chemical analyses}

Measurements of water $\mathrm{pH}$, temperature, electrical conductivity (EC) and total soluble salts (TSS) were tested using a $\mathrm{pH}$ meter (Cole-parmer pH bench-top) model MX-59003-20 and EC meter (Cole-parmer EC bench-top) model MX-1995000 .

The anions and heavy metals were determined according to Black (1965), while the concentration of nitrates was measured using a standard autoanalyzer.
The concenteration of chromium (cr), nickel (ni), mercury (hg), cobalt (Co), zinc (zn), copper (cu), lead (pb) and cadmium (cd) were determined by inductivity coupled spectrometer plasma (ICP), Plasma 400.

\subsection{Microbiological analyses}

2.3.1. Enumeration, isolation and identification of microorganisms from water samples

The standard agar plate method was used for the determination of total viable counts on glucose- yeast extract agar (Postage, 1969). Plates were incubated at $37^{\circ} \mathrm{C}$ for $48 \mathrm{~h}$.

Colstridia and Bacillus cereus were enumerated as described by Difco (1984) and Holt et al., (1994), respectively. Counts of staphylococci were determined using Baird-parker agar (Baird Parker, 1962) and identified according to Holt et al., (1994). The MPN of total and feacal coliform were obtained using MacoConkey broth medium incubated at $37{ }^{\circ} \mathrm{C}$ and $44.5{ }^{\circ} \mathrm{C}$ for $24 \mathrm{~h}$, respectively (Difco, 1984). Existence of Salmonella was detected according to A.O.A.C. (1998) and identified according to Holt et al., (1994). The Aeromonas were determined following the method of Rippey and Cabelli (1979) and were confirmed to genus Aeromonas 
medium and all isolates were subjected to purification and identified according to Rippka et al., (1979).

\subsubsection{Maintenance and culturing conditions}

All isolates obtained were maintained under photoautotrophic growth conditions in Allen and Arnon's medium (Allen and Arnon, 1955). Both enrichment and stock cultures were grown under continuous illumination, with Philips Fluorescent white lamps, at a relatively low light intensity (400-500 lux) and incubated at $30^{\circ} \mathrm{C}$.

\subsubsection{Cyanobacterial metabolites assay}

Three cyanobacterial isolates were inoculated in Allen and Arnon broth, incubated at $30^{\circ} \mathrm{C}$ in light intensity about 400, 500 lux for 30 days and

\subsubsection{Disc diffusion method}

Disc diffusion method was carried out to determine the antimicrobial activity according to Sleigh and Timburg (1981). Antimicrobial activity was measured as diameter $(\mathrm{mm})$ of growth inhibition zones around loaded filter disc.

Statistical analyses were carried out using SAS (1990). Variables having a significant differences were compared using Duncan`s multiple range test (Duncan, 1955).

\section{RESULTS AND DISCUSSION}

\subsection{Physical and chemical analyses of water samples}

The chemical analysis of the different water

Table (2): Some properties of the tested water samples .

\begin{tabular}{|c|c|c|c|c|c|c|c|c|c|c|c|c|}
\hline \multirow[b]{2}{*}{ Samples } & \multicolumn{3}{|c|}{ pH } & \multicolumn{3}{|c|}{$\begin{array}{c}\text { Samples } \\
\text { Temperature }\left({ }^{\circ} \mathrm{C}\right)\end{array}$} & \multicolumn{3}{|c|}{ E.C. (m mohs/cm) } & \multicolumn{3}{|c|}{ T.S.S. (ppm) } \\
\hline & 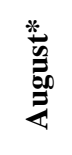 & 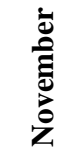 & 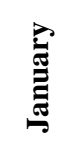 & 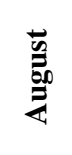 & $\begin{array}{l}\dot{\bar{\nu}} \\
\stackrel{0}{0} \\
\overline{0} \\
\dot{0} \\
\text { Z }\end{array}$ & 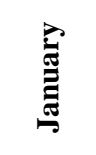 & 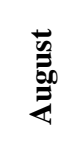 & 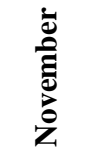 & 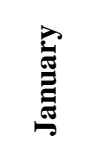 & 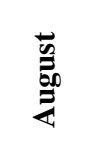 & $\begin{array}{l}\dot{\Xi} \\
\bar{\Xi} \\
\bar{\Xi} \\
\grave{Z}\end{array}$ & $\begin{array}{l}\vec{E} \\
\stackrel{\Xi}{\Xi} \\
\stackrel{\Xi}{\Xi}\end{array}$ \\
\hline H1 & 8.0 & 8.26 & 8.13 & 32 & 20.1 & 26.05 & 0.51 & 0.419 & 0.464 & 234.6 & 192.7 & 213.6 \\
\hline H2 & 7.9 & 8.18 & 8.04 & 31 & 20 & 25.5 & 0.52 & 0.434 & 0.477 & 239.2 & 199.6 & 219.4 \\
\hline H3 & 8.0 & 8.20 & 8.10 & 29 & 20 & 24.5 & 0.52 & $\mathbf{0 . 4 3}$ & 0.475 & 239.2 & 197.8 & 218.5 \\
\hline G1 & 7.9 & 8.18 & 8.04 & 32.5 & 22.1 & 27.3 & 0.52 & 0.454 & 0.487 & 239.2 & 208.8 & 224.0 \\
\hline G2 & 7.0 & 8.23 & 7.61 & 31 & 22 & 26.5 & 0.53 & 0.444 & 0.487 & 243.8 & 204.2 & 224.0 \\
\hline G3 & 7.2 & 8.30 & 7.75 & 28 & 22 & 25 & 0.53 & 0.44 & 0.484 & 242.8 & 202.4 & 222.6 \\
\hline $\mathbf{R} 1$ & 8.1 & 8.28 & 8.19 & 33 & 23.5 & 28.2 & 0.45 & 0.431 & 0.465 & 229.5 & 198.2 & 213.9 \\
\hline $\mathbf{R 2}$ & 8.0 & 8.30 & 8.15 & 32 & 23.8 & 27.9 & 0.50 & 0.43 & 0.465 & 230.0 & 197.8 & 213.9 \\
\hline R3 & 8.2 & 8.32 & 8.26 & 29 & 22.5 & 25.7 & 0.50 & 0.43 & 0.465 & 230.0 & 197.8 & 213.9 \\
\hline
\end{tabular}

* Five samples collected at each sampling date

centrifuged to separate biomass. The culture supernatants were used for studying their antimicrobial active metabolites against a number of microorganisms using the disc diffusion method (Abdel-Moein and Barakat, 2005). The test microorganisms representing Gram-negative bacteria (E. coli, Pseudomonas aerogenosa, Salmonella typhimurium), Gram-positive bacteria (Micrococcus spp., Bacillus subtilis, Sarcina spp., Staphylococcus aureus, Listeria monocytogenes) and acid fast bacteria (Mycobacterium phlei) were used in the present study. Such strains were obtained from the Department of Agricultural Microbiology, Fac. Agric., Cairo University and grown in a nutrient glucose agar medium. samples ( Tables 2 and 3 ) reveals that the $\mathrm{pH}$ of the water which ranged between 7.0 and 8.2 and the temperature differed according to the time of sampling from 20 to $32.5{ }^{\circ} \mathrm{C}$. Treatment of the river Nile raw water reduced the E.C and the total soluble salts (T.S.S.). This, obviously, was due to the partial removal of some of the suspended and soluble salts from the raw water during treatment process.

Regarding the heavy metal contents of the examined water, the drinking water was free from $\mathrm{Hg}, \mathrm{Co}, \mathrm{Pb}$ and $\mathrm{Cd}$, while, $\mathrm{Cr}$ and $\mathrm{Cu}$ existed in concentrations ranged between $0-651.12$ and 2.3$84.13 \mu \mathrm{g} / \mathrm{l}$, respectively. In addition, zinc and $\mathrm{Ni}$ were detected in all samples but in lower 
quantities e.g. 1.51-48.91 and $0-59.47 \mu \mathrm{g} / \mathrm{l}$, respectively compared with $\mathrm{Cr}$ and $\mathrm{Cu}$. In some cases, the heavy metal contents of raw water increased by treatment processes. This observation lowest microbial count was observed in water samples taken from Giza treatment plant while the highest was recorded in the raw water sample from Helwan. However, their counts were reduced

Table (3): Anions, cations and heavy metals $(\mu \mathrm{g} / \mathrm{L})$ content of the collected water samples.

\begin{tabular}{|c|c|c|c|c|c|c|c|c|c|}
\hline \multicolumn{10}{|c|}{ Water samples* } \\
\hline & G1 & G2 & G3 & R1 & $\mathbf{R} 2$ & R3 & H1 & H2 & H3 \\
\hline \multicolumn{10}{|c|}{ Anions } \\
\hline Cl & 18.00 & 4.00 & 3.00 & 9.00 & 1.00 & 1.00 & 7.00 & 7.00 & 5.00 \\
\hline $\mathrm{NO}_{3}$ & 331.00 & 11.00 & $\begin{array}{l}10.00 \\
\end{array}$ & 335.00 & $\begin{array}{ll}16.00 \\
\end{array}$ & 16.00 & 13.00 & 333.00 & 333.00 \\
\hline \multicolumn{10}{|c|}{ Cation } \\
\hline $\mathbf{N H}_{4}$ & $\overline{778.00}$ & 443.00 & 390.00 & 617.00 & 130.00 & 120.00 & 361.00 & 370.00 & 330.00 \\
\hline \multicolumn{10}{|c|}{ Heavy metals } \\
\hline $\mathbf{C r}$ & 3.22 & 530 & 531 & 651.12 & 1.39 & 1.6 & ND & 1.10 & 1.2 \\
\hline $\mathbf{N i}$ & 1.05 & 218.83 & 213 & $\mathbf{5 9 4 . 7 7}$ & ND & ND & 297.39 & 185.16 & 186.18 \\
\hline $\mathbf{Z n}$ & 1.51 & $\begin{array}{l}48.91 \\
\end{array}$ & 49.3 & 4.97 & 3.01 & 3.3 & 12.01 & 2.54 & 2.6 \\
\hline $\mathbf{C u}$ & $\begin{array}{l}3.17 \\
\end{array}$ & 84.13 & \begin{tabular}{|l|l|}
84.70 \\
\end{tabular} & 2.66 & 66.32 & 666.90 & 2.52 & 2.33 & 2.8 \\
\hline
\end{tabular}

* For explanation refer to Table (1); ND, not determined.

is in conformity with that reported by El-Gendi (2003) indicating the increase in heavy metal contents of drinking water due to the processes of water treatments.

\subsection{Microbiological analyses of water samples}

The occurrence of microbial pathogen in raw, treated or tap water poses a considerable human health hazard. Water-borne human diseases are considered as a major limiting factor in drinking water quality. Different microbial densities in water samples are presented in Tables $(4,5$ and 6$)$ and Fig. (1). Data show that the total microbial count ranged between $0.5 \times 10^{7}$ and $2.9 \times 10^{7}$ $\mathrm{cfu} / \mathrm{ml}$ in raw water samples. In this respect, the to a minimum of $0.2 \times 10^{2} \mathrm{cfu} / \mathrm{ml}^{-1}$ as a result of water treatment in Rod El-Farag. This trend was also observed with regard to the total count of spore-forming bacteria. The traditional indicators of water pollution e.g., total and faecal coliforms, E. coli, Salmonella and Staphyllococus were detected in all samples of raw water but not in the treated water (Tables, 5 and 6). This might indicate the efficiency of the water treatment processes in the examined plants. In this respect, the river Nile water at Helwan area was less polluted than the other sites. This could be suggested by comparing the counts of the total,

Table (4): Total viable count and total spore-forming bacteria (cfu $\left.\mathrm{ml}^{-1}\right)$ in raw and treated water samples.

\begin{tabular}{|c|c|c|c|c|c|c|}
\hline & \multicolumn{6}{|c|}{ Total count } \\
\hline & \multicolumn{3}{|c|}{ Raw water $\left(\times \mathbf{1 0}^{7}\right)$} & \multicolumn{3}{|c|}{ Treated water $\left(\mathrm{x} 10^{2}\right)$} \\
\hline & August & November & January & August & November & January \\
\hline Giza & 2.90 & 1.00 & 1.40 & 1.30 & 0.50 & 0.60 \\
\hline Rod El-Farag & 2.30 & 0.80 & 1.90 & 0.50 & 0.00 & 0.40 \\
\hline Helwan & 1.20 & 0.50 & 0.70 & 0.70 & 0.20 & 0.50 \\
\hline \multirow[t]{4}{*}{ LSD (0.05) } & 0.358 & 0.132 & 0.212 & 0.154 & 0.052 & 0.085 \\
\hline & \multicolumn{6}{|c|}{ Spore forming } \\
\hline & \multicolumn{3}{|c|}{ Raw water $\left(\mathbf{x ~ 1 0}^{7}\right)$} & \multicolumn{3}{|c|}{ Treated water $\left(\times 10^{2}\right)$} \\
\hline & $\underset{\mathbf{t}}{\text { Augus }}$ & November & January & August & November & January \\
\hline Giza & 1.90 & 1.00 & 1.30 & 0.40 & 0.20 & 0.30 \\
\hline Rod El-Farag & 1.40 & 0.20 & 0.90 & 0.30 & 0.20 & 0.00 \\
\hline Helwan & 1.70 & 0.50 & 1.60 & 1.30 & 0.20 & 0.40 \\
\hline LSD(0.05) & 0.296 & 0.199 & 0.231 & 0.156 & Ns 0.035 & 0.058 \\
\hline
\end{tabular}

ns. non significant. 
faecal coliforms and staphylococci in the raw water at all sites.

Pathogenic B. cereus and Clostridium sp. were detected in relatively high numbers in all raw water samples (Table, 6), while drinking water samples were clostridia free. Unexpectedly, $B$. cereus was observed in all the tested tap water samples but in low numbers of 1 and $5 \times 10^{1}$ $\mathrm{cfu} / \mathrm{ml}$.
(2006) isolated E.coli and Salmonella from fresh water in Lebanon. While Hamner et al., (2007) detected E.coli serotype 0157:H7 from the Ganges river in India. In addition, El-Taweel and Shaban (2001) reported the presence of some pathogenic bacteria in drinking water from some tested drinking water treatment plants in Egypt.

However, Aeromonds and Vibrio cholera were

Table (5): Count (cells/ml) of total and faecal coliform in water samples.

\begin{tabular}{|c|c|c|c|c|c|c|}
\hline \multirow{3}{*}{$\begin{array}{c}\text { Water } \\
\text { samples }\end{array}$} & \multicolumn{6}{|c|}{ Coliform (cells/ml) } \\
\hline & \multicolumn{3}{|c|}{ Total } & \multicolumn{3}{|c|}{ Faecal } \\
\hline & August & November & January & August & November & January \\
\hline G1 & $1.5 \times 10^{7}$ & $1 \times 10^{7}$ & $1.3 \times 10^{7}$ & $1 \times 10^{7}$ & $0.8 \times 10^{7}$ & $0.9 \times 10^{7}$ \\
\hline $\mathrm{R} 1$ & $1.5 \times 10^{7}$ & $0.8 \times 10^{7}$ & $1.5 \times 10^{7}$ & $1 \times 10^{7}$ & $0.2 \times 10^{7}$ & $0.3 \times 10^{7}$ \\
\hline H1 & $1 \times 10^{7}$ & $0.7 \times 10^{7}$ & $0.9 \times 10^{7}$ & $0.8 \times 10^{7}$ & $0.2 \times 10^{7}$ & $0.8 \times 10^{7}$ \\
\hline
\end{tabular}

Table (6): Total count of some pathogenic bacteria in water samples.

\begin{tabular}{|c|c|c|c|c|c|c|c|}
\hline $\begin{array}{l}\text { Water } \\
\text { samples }\end{array}$ & 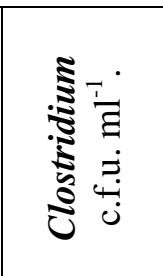 & 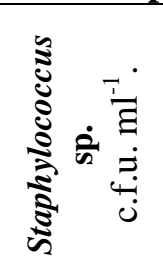 & 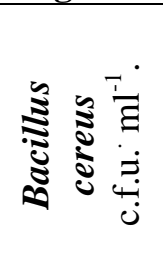 & 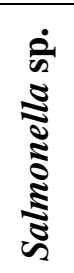 & 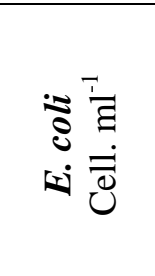 & 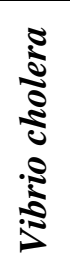 & 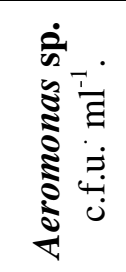 \\
\hline G1 & $2.5 \times 10^{4}$ & $9.0 \times 10^{2}$ & $4.2 \times 10^{2}$ & D & $1.3 \times 10^{7}$ & ND & $8 \times 10^{2}$ \\
\hline G2 & ND & ND & $2 \times 10^{1}$ & ND & ND & ND & ND \\
\hline G3 & ND & ND & $2 \times 10^{1}$ & ND & ND & ND & ND \\
\hline R1 & $2.5 \times 10^{4}$ & $1.8 \times 10^{2}$ & $1.2 \times 10^{8}$ & D & $0.3 \times 10^{7}$ & ND & $2 \times 10^{3}$ \\
\hline $\mathbf{R 2}$ & ND & ND & $7 \times 10^{1}$ & ND & ND & ND & ND \\
\hline R3 & ND & ND & $1 \times 10^{1}$ & ND & ND & ND & ND \\
\hline H1 & $2.5 \times 10^{3}$ & $8 \times 10^{2}$ & $60 \times 10^{2}$ & D & $8 \times 10^{7}$ & ND & $7 \times 10^{2}$ \\
\hline H2 & ND & ND & ND & ND & ND & ND & ND \\
\hline H3 & ND & ND & $5 \times 10^{1}$ & ND & ND & ND & ND \\
\hline LSD (0.05) & 0.327 & 0.200 & 0.421 & & 0.512 & & 1.558 \\
\hline
\end{tabular}

The presence of $B$. cereus in these samples could be attributed to that Bacillus, being able to form endospores of high persistence against harsh conditions and can tolerate the different processes applied during water treatment. Previous reports indicated the possible existence of some Gnegative bacteria in some Egyptian drinking waters (El-Taweel, 2003). Also Harakeh et al., not found in both treated water and tap water samples, while Aeromonds was found in raw water without evidence for the presence of Vibrio cholera. The presence of the pathogen Aeromonas hydrophilia in fresh water was reported in USA (Katz and Smith, 1980) and in Egypt (El-Taweel, 2003). 


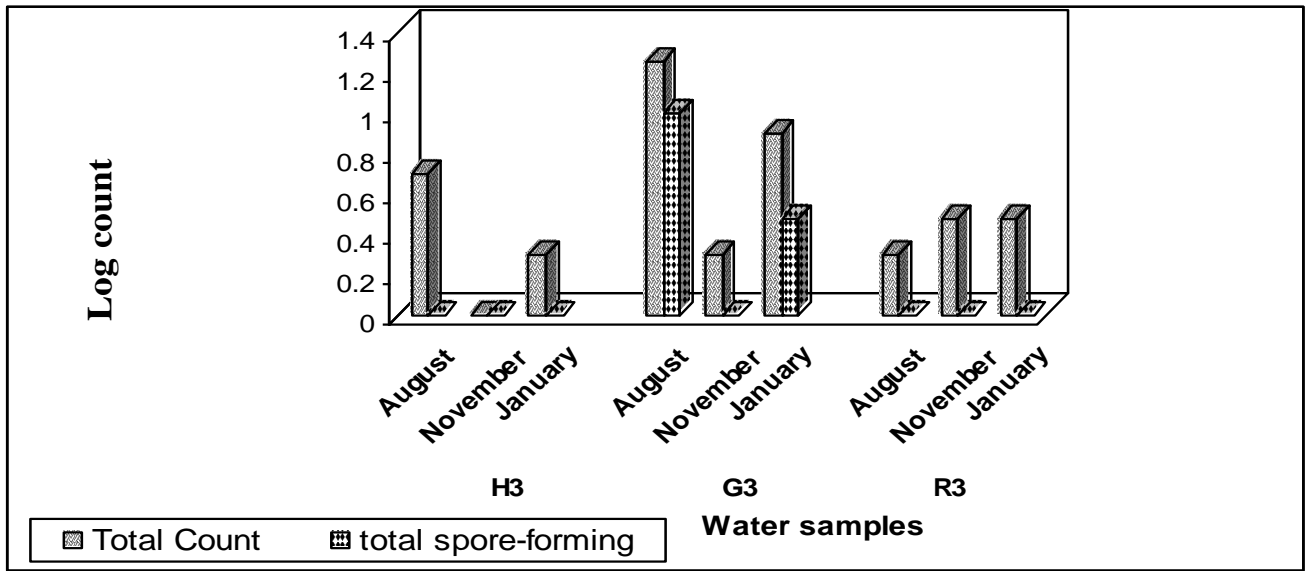

Fig. (1):Total viable count (log counts) and total spore-forming bacteria in tap water.

\subsection{Identification of bacterial isolates}

Two hundred bacterial isolates were obtained from representative colonies developed on the specific media of Staphylococci, Salmonella, B. cereus and Aeromonas. Isolates were purified and examined for cultural, morphological and biochemical characteristic (Fig. 2). Fifty three Gram-positive, catalase positive cocci were isolated from plates of the specific media for counting staphylococci in raw water samples. These isolates were differentiated according to
Holt et al., (1994) into Micrococcus spp.(25\%) and Staph. aureus (75\%). Drinking water samples were free from Staph. aureus and all the identified Staph aureus strains were originated from the raw river Nile samples taken from Giza (33.4\%) and Rod El-Farag (66.6\%). This might refer to heavy water pollution of the river Nile water stream at Rod El-Farag and Giza locations. B. cereus ( 75 strains) was isolated from all water samples except to the treated water samples from Helwan. Strains were confirmed as B.cereus as

\section{All isolates (215 isolates) \\ Cyanobacterial isolates( 15 isolates) \\ - Anabaena sp. (8) and Calothrix sp. (3), from Giza \\ - Gloeocapsa sp. (4), from Helwan}

\section{Bacterial isolates ( 200 isolates)}

- B. cereus (75 isolates)

From raw water and treated water except the treated water sample from Helwan

- Aeromonas spp. (51 isolates)

○ schubertii (9),

○ hydrophila (2),

$\circ$ veronii (1),

○ subsp. smithia (4) and $\circ$

- Salmonella (21 isolates)

○ S. choleraesuis (6),

- S. pullorum (8) and

- Staphylococci (53 isolates)

○ eucrenophila (8),

- media (17),

- salmonicida, subsp. salmonicida (9),

subsp. achromogenes (1).
○ S. gallinarum (3),

○ S. typhi (4)

○ Staph. aureus (40) and ○ Micrococcus sp.(13)

Fig. (2): Description of microbial isolates obtained from the tested water samples (Number of isolates from each species is shown between brackets). 
described by Sneath et al., (1986).

$B$. cereus, have the ability to form endospores with extraordinary persistence against harsh conditions which might explain the high frequency occurrence of such health-hazardous bacterium in raw water from all sampling sites and treated water samples from Giza and Rod ElFarag. Water treatment processes seemed to be insufficient for complete elimination of B. cereus from treated water which suggests considerable concern of this bacterium in water quality standards. The presence of $B$. cereus in drinking water samples at the distribution system in Helwan might indicate the recontamination of treated water through the distribution network.

Twenty one isolates of Salmonella were exclusively recovered from raw water samples. The isolates were differentiated according to Holt et al., (1994) into four species; S. choleraesuis (28.6\%), S. gallinarum (14.2\%), S. pullorum $(38 \%)$ and S. typhi $(19.1 \%)$. The raw water of Helwan harbored Salmonella of the four species while no $S$. pullorum strains could be obtained from Giza site and $S$. choleraesuis was not distinguished in raw water from Rod El-Farag. Fifty one isolates of Aeromonas spp. were identified according to Popoff (1984) and ElTaweel (2003). Their traits related to A. schubertii (17.6\%), A. eucrenophila (15.7\%), A. hydrophila
(3.9\%), A. media (33.3\%), A. veronii (2\%), A. salmonicida, subsp. Salmonicida (17.6\%), subsp. Smithia (7.9\%) and subsp. Achromogenes $(2 \%)$.

\subsection{Isolation and identification of cyanobacteria from water samples}

Many species of cyanobacteria have the potentiality to produce toxins that present a hazard to human health. Some genera can produce offensive taste and odours, and hence cause problems in drinking water derived from an affected source (Ouellette and Wilhelm, 2003). A total of 15 cyanobacterial isolates was identified according to Rippka et al., (1979) as Anabaena sp., Calothrix sp. and Gloeocapsa sp. The Anabaena sp., Calothrix sp. were isolated from raw water at Giza plant, while, Gloeocapsa sp. was isolated from raw water and treated water at Helwan. Zakaria (2007) isolated the toxic cyanobacterial strains i.e. Cylindrospermopsis raciborskii and Raphidiopsis mediterranea, which produce hepatotoxin and neurotoxin, respectively, in Egyptian fresh water.

\subsection{Antimicrobial activities of some}

\section{cyanobacterial metabolites}

Three isolates of cyanobacteria were examined for the production of their metabolites in liquid cultures adopting the disc diffusion method (Table, 7).

Table (7): Antimicrobial activities of cyanobacterial metabolites.

\begin{tabular}{|c|c|c|c|c|c|c|c|c|}
\hline \multirow{3}{*}{ Bacterial Strains } & \multicolumn{7}{|c|}{ Diameter of clear zone of inhibition (mm) } & \multirow{3}{*}{$\begin{array}{c}\text { LSD } \\
(0.05)\end{array}$} \\
\hline & \multirow{2}{*}{ Control } & \multicolumn{2}{|c|}{ C I } & \multicolumn{2}{|c|}{ C I } & \multicolumn{2}{|c|}{ C III } & \\
\hline & & $\mathbf{M}$ & $\mathrm{C}$ & $\mathbf{M}$ & $\mathrm{C}$ & $\mathbf{M}$ & $\mathrm{C}$ & \\
\hline & \multicolumn{7}{|c|}{ Gram- negative bacteria } & \\
\hline E. coli & $\mathbf{0}$ & ND & 3.00 & ND & 2.00 & ND & 1.00 & 0.03 \\
\hline Pseudomonas aerogenosa & $\mathbf{0}$ & ND & 2.00 & ND & 1.00 & ND & 2.00 & 0.02 \\
\hline \multirow[t]{2}{*}{ Salmonella typhimurium } & $\mathbf{0}$ & ND & 3.00 & ND & 2.00 & ND & ND & 0.044 \\
\hline & \multicolumn{7}{|c|}{ Gram- positive bacteria } & \\
\hline Micrococcus sp. & $\mathbf{0}$ & ND & 5.00 & ND & 4.00 & ND & 4.00 & 0.06 \\
\hline Bacillus subtilis & $\mathbf{0}$ & 2.00 & 7.00 & ND & 5.00 & ND & 4.00 & 0.075 \\
\hline Sarcina sp. & $\mathbf{0}$ & ND & 1.00 & ND & 3.00 & ND & 2.00 & 0.03 \\
\hline Staphylococcus aureus & $\mathbf{0}$ & ND & 1.00 & ND & 1.00 & ND & 2.00 & 0.016 \\
\hline \multirow[t]{2}{*}{ Listeria monocytogenes } & $\mathbf{0}$ & ND & 4.00 & ND & 3.00 & ND & 2.00 & 0.044 \\
\hline & \multicolumn{7}{|c|}{ Acid fast bacteria } & \\
\hline Mycobacterium phlei & $\mathbf{0}$ & 2.00 & 4.00 & 2.00 & 5.00 & ND & 2.00 & 0.057 \\
\hline
\end{tabular}


The crude culture supernatants had no effect on growth of all tested microorganisms except with $B$. subtilis and $M$. phlei cultures where the diameters of growth inhibition zones were $2 \mathrm{~mm}$. Therefore, the crude culture supernatants were concentrated by dehydration using the freeze drying method.

The concentrated supernatant suppressed growth of all the test bacterial members. Bacillus subtilis showed higher sensitivity towards the concentrated supernatant. Among cyanobacteria, Anabaena sp. produced the most antimicrobial active metabolites forming a growth inhibition zone of $7 \mathrm{~mm}$ diameter in Bacillus subtilis culture plates. Cyanobacteria produce a wide variety of chemically unique secondary metabolites including toxins that have a harmfull effect on other tissues, cells or organisms (Carmichael, 1992) and may function as protective compounds (Demott et al., 1991). Cyanobacteria toxins are grouped into cyanotoxins and biotoxins based on the type of bioassay used to screen for their activity. Cyanotoxins are not highly lethal to animals but have a wide spectrum of bioactivity against algae, bacteria, fungi and mammalian cell lines which are used to detect them especially tummer cell lines. (Carmichael, 1992).

Biotoxins assayed with small animals (mice or aquatic invertebrates) and have been responsible worldwide for repeated cases of sickness and death in livestock, pets and wild life after ingestion of water containing toxic algae. Biotoxins include neurotoxins which are commonly produced by the Anabaena and Oscillatoria species, while hepatoxins are produced by the microcystis and Cylindrospermopsis (Ouellette and Wilhelm, 2003). In this concern, Ronald et al.,(2005) isolated approximately 70 microcysitins (cyclic hepatotoxins) variants.The obtained results indicate that the antagonistic activities of cyanobacterial metabolites produced by the examined isolates of Anabaena sp., Calothrix sp. and Gloeocapsa sp. needs further studies on the optimal conditions for maximal production of such metabolites by the different cyanobacterial isolates. Isolation, chemical fractionation and biological assays of these metabolites are also required in order to clarify their mode of action against human cells which might lead to a possible pharmaceutical applications.

\section{REFERENCES}

Abdel-Moein N.M. and Barakat O.S. (2005). Biochemical and biological studies on cat thyme (Teucrium polium L.). J. Agric. Sci. Mansoura Univ., 30, 10: 6453-6465.

Adam C.M., Albrechtsen H.J., Arvin E. and Molin S. (2005). Identification of bacteria in biofilm and bulk water samples from a nonchlorinated model drinking water distribution system: detection of a large nitrite-oxidizing population associated with Nitrospira spp. Appl. Environ. Microbiol., 71,12: 8611-8617.

Allen M.B. and Arnon D.I. (1955). Growth and nitrogen fixation by Anabaena cylindrical. Plant Physiol. 30: 366-372.

A.O.A.C. (Association of Official Analytical Chemistry) (1998). Official Methods of Analysis. $16^{\text {th }}$ ed. (W. Hortwitz., ed.) Washington DC,

APHA (American Public Health Associantion) (1985). American Water Works Association; Water Pollution Control Federation. Standard Methods For The Examination of Water and Wastewater. $16^{\text {th }}$.ed. Washington: 1268pp.

Baird-Parker, A.C. (1962). The occurrence and enumeration of micrococci and staphylococci in becon and on human and pig skin. J. Appl. Bact., 25:253-61.

Black C.A. (1965). Methods of Soil Analysis. Part. 1. Am. Soc. Agron. Madison, Wisconsin (ed. C.A. Black).

Carmichael W. W. (1992). Cyanobacteria secondary metabolites - the cyanotoxins. J. Appl. Microbiol. 72:445-459.

Carmichael W. W. (1994). The toxins of cyanobacteria. Sci. Am. 270:78-86.

Demott W. R., Zhang Q. X. and Carmichael W. W. (1991). Effects of toxic cyanobacteria and purified toxin on the survival and feeding of a copepod and three species of Daphnia. Limnology and Oceanography.36: 1346-1357.

Difco Manual (1984). Dehydrated Culture Media and Reagents for the Microbiology. $10^{\text {th }}$ ed. Difco Lab., Detriot, Michigan, USA.

Duncan D.B. (1955). Multiple range and multiple F-Test. Biometrics. 11:1-42.

EL-Gendi S.A. (2003). Speciation of some of heavy metals in some waters of Egypt. Egypt. J. Soil Sci. 43, 2: 211-221.

El-Taweel G.E. (2003). Association between Aeromonas spp. and classical bacterial indicators of pollution in different aquatic environments. Egypt. J. Microbiol. 38, 3: 265281.

El-Taweel G.E. and Shaban A.M. (2001). Microbiological quality of drinking water at eight water treatment plants, Int. J. Environ. Health Res., 11, 4: 285-290. 
Emtiazi F., Schwartz T., Marten S.M., KrollaSidenstein P. and Obst U. (2004). Investigation of natural biofilm formed during the production of drinking water from surface water embankment filtration. Water Res. 38:1197-1206.

Hamner S., Broadaway S.C., Mishra V.B., Tripathi A., Mishra R.K., Pulcini E., Pyle B.H. and Ford T.E. (2007). Isolation of potentially pathogenic Escherichia coli O157:H7 from the Ganges river. Appl. Environ. Microbiol. 73: 2369-2372.

Harakeh S., Yassine H. and El-Fadel M. (2006). Antimicrobial-resistant patterns of Escherichia coli and Salmonella strains in the aquatic Lebanese environments Environ. Poll., 143, 2: 269-277.

Holt J.G., Krieg N.R., Sneath P.H.A., Staley J.T. and Williams S.T. (1994). Bergey's Manual of Determinative Bacteriology. $9^{\text {th }}$ ed. Baltimore, Maryland: Williams and Wilkins.

Katz D. and Smith H. (1980). Aeromonas hydrophila infection of a puncture wound. Annals of Emergency Medicine. 9,10: 529531.

LeChevallier, M.W. (1990). Coliform regrowth in drinking water: A review. J. Am. Water Works Assoc. 82:74-86.

Lee D.G. and Kim S.J. (2003). Bacterial species in biofilm cultivated from the end of the Seoul water distribution system. J. Appl. Microbiol., 95:317-324.

Lehtola M.J., Torvinen E., Kusnetsov J., Pitkänen T., Maunula L., von Bonsdorff C.H., Martikainen P.J., Wilks S.A., Keevil C.W. and Miettinen I.T. (2007). Survival of Mycobacterium avium, Legionella pneumophila, Escherichia coli, and caliciviruses in drinking water biofilms grown under high shear turbulent flow. Appl. Environ. Microbiol., 73: 2854-2859.

Monfort P. and Baleux B. (1990). Dynamics of Aeromonas hydrophilla, Aeromonas sobria and Aeromonas caviae in a sewage treatment pond., Appl. Environ. Microbiol., 56, 7: 1999-2006.

Norton, C.D. and LeChevallier M.W. (2000). A pilot study of bacteriological population changes through potable water treatment and distribution. Appl. Environ. Microbiol., 66:268-276.

Oliver J.D. (2000). The Public Health Significance Of Viable But Nonculturable Bacteria. In: Nonculturable Microorganisms in the Environment. Colwell, R.R. and
Grimes, D.J. (eds), ASM Press, Washington, DC, p. 277-300.

Ouellette A.J. and Wilhelm S.W. (2003).Toxic cyanobacteria: the evolving molecular toolbox. Front Ecol. Environ., 1, 7: 359-366.

Popoff M. (1984). Genus III. Aeromonas Kluyver and Van Niel 1936, 398AL, In : Bergey`s Manual of Systematic Bacteriology, N.R. Krieg and J.G. Holt (ed.), The Williams \& Wilkuns Co., Baltimore. 1: 545-548.

Postage J.R. (1969).Viable Counts and Viability. In : Methods in Microbiology Norris, J.R., Robbens, D.W. (eds.)., Academic Press, London., N.Y. 1:611-628.

Rippey S.R. and Cabelli V.J. (1979). Membrane filter procedure for enumeration of Aeromonas hydrophilla in fresh waters., Appl. Environ. Microbiol., 38: 108-113

Rippka R., Deruelles J., Waterbury J.B., Herdman M. and Stander R.Y. (1979). Generic assignments, strain histories and properties of pure cultures of cyanobacteria. J. Gen. Microbiol., 111: 1-61.

Ronald W.Z., Chen H., Burke J.M. and Prepas E.E. (2005). Hepatotoxic Cyanobacteria: A review of the biological importance of microcystins in freshwater environments. Journal of Toxicology and Environmental Health Part B: Critical Reviews. 8,1: 1-37.

SAS Institute Inc. (1990). SAS User's Guide: Statistics. SAS Ins. Inc., Cary, Nc.

Sleigh J.D. and Timburg M.C. (1981). Notes on Medical Bacteriology, Churchill Livingstone, London, p.43.

Sneath P.H.A., Mair N.S., Sharpe M.E. and Holt, J.G. (1986). Bergey's Manual of Systematic Bacteriology. Vol. 2, Baltimore, Maryland: Williams and Wilkins. Co.

Stefan E., Richard C., Claudia H., Petra W., Julia B., Ingrid B., Arndt M. and Manfred G.H. (2006). Composition and dynamics of bacterial communities of a drinking water supply system as assessed by RNA- and DNA-based 16S rRNA gene fingerprinting. Appl. Environ. Microbiol., 72, 3: 1858-1872.

Wagner M. and Loy A. (2002). Bacterial community composition and function in sewage treatment systems. Curr. Opin. Biotechnol., 13:218-227.

Zakaria A.M. (2007). First report of toxic Cylindrospermopsis raciborskii and Raphidiopsis mediterranea (Cyanoprokaryota) in Egyptian fresh waters. FEMS Microbiol. Ecol., 59(3): 749-761. 


\section{التقييم الحيوي الكيميائي لبعض محطات مياه الثرب علي نهر النيل بمصر}

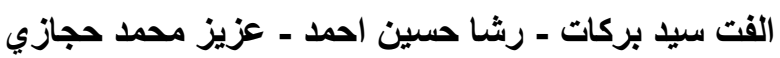

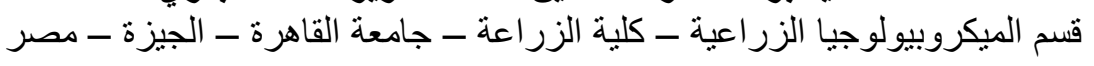

\section{ملخص}

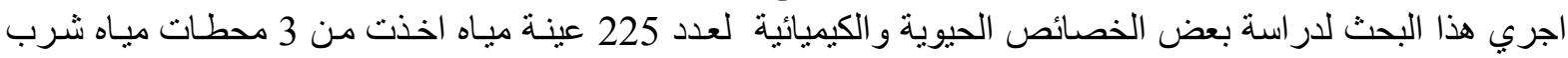

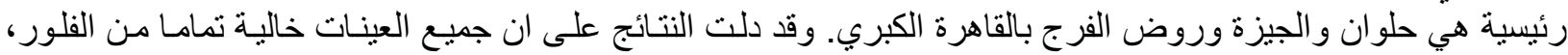

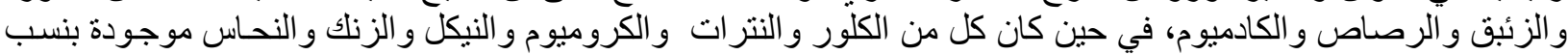
مختلفة في عينات المياه المختبرة.

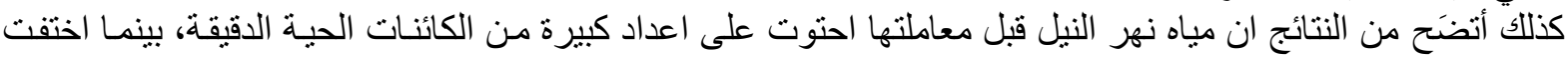

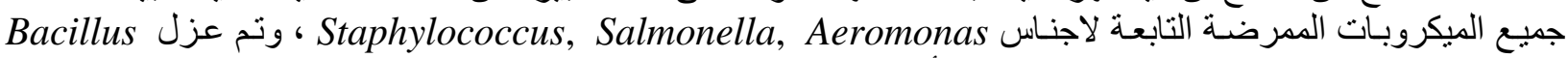
cyanobacteria g cereus

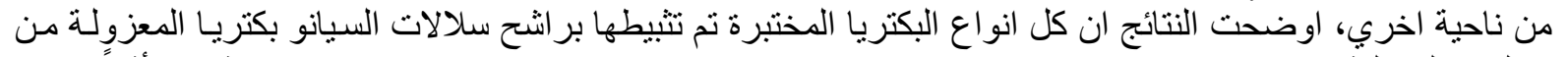

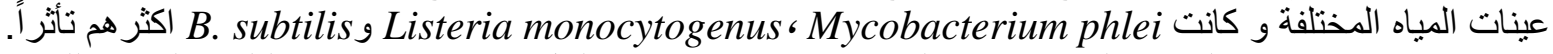

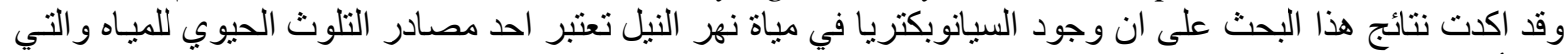

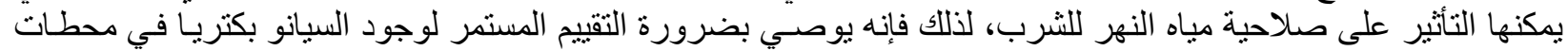
مياة الثرب.

المجلة العلمية لكلية الزراعة - جامعة القاهرة - المجلد (59) العدد الثناني ( إبريل 2008): 132-141. 


\section{التقييم الحيوي الكيميائي لبعض محطات مياه الثرب علي نهر النيل بمصر

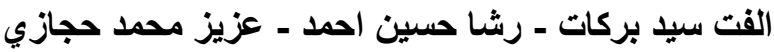

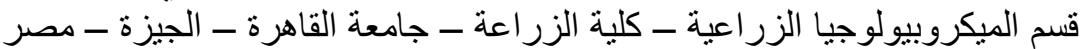

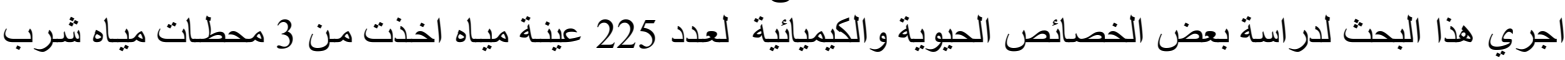

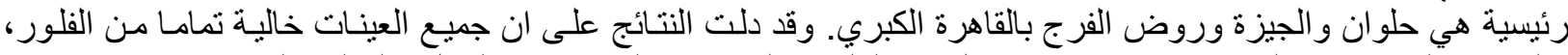

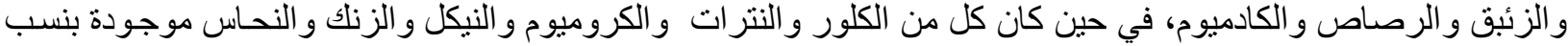
مختلفة في عينات المياه المختبرة.

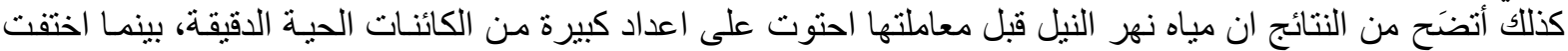

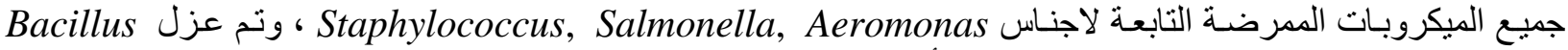
cyanobacteria g cereus

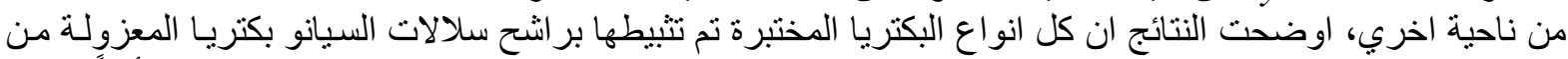

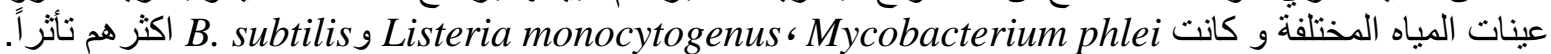

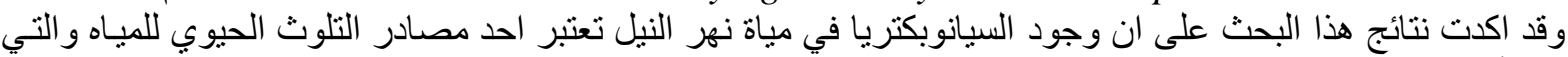

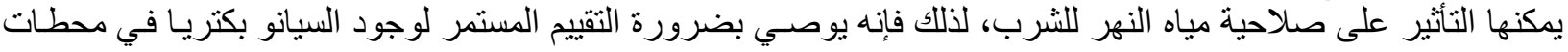
المجلة العلمية لكلية الزر اعة - جامعة القاهرة - المجلد (59) العدد الثاني ( إبريل 2008): 132-141. 